National Water-Quality Assessment Program

Electron Donor Concentrations in Sediments and Sediment Properties at the Agricultural Chemicals Team Research Site near New Providence, lowa, 2006-07

Data Series 737 



\section{Electron Donor Concentrations in Sediments and Sediment Properties at the Agricultural Chemicals Team Research Site near New Providence, lowa, 2006-07}

By Bijesh Maharjan, Scott F. Korom, and Erik A. Smith

National Water-Quality Assessment Program

Data Series 737 


\section{U.S. Department of the Interior \\ KEN SALAZAR, Secretary \\ U.S. Geological Survey \\ Marcia K. McNutt, Director}

\section{U.S. Geological Survey, Reston, Virginia: 2013}

For more information on the USGS - the Federal source for science about the Earth, its natural and living resources, natural hazards, and the environment, visit http://www.usgs.gov or call 1-888-ASK-USGS.

For an overview of USGS information products, including maps, imagery, and publications, visit http://www.usgs.gov/pubprod

To order this and other USGS information products, visit http://store.usgs.gov

Any use of trade, firm, or product names is for descriptive purposes only and does not imply endorsement by the U.S. Government.

Although this information product, for the most part, is in the public domain, it also may contain copyrighted materials as noted in the text. Permission to reproduce copyrighted items must be secured from the copyright owner.

Suggested citation:

Maharjan, Bijesh, Korom, S.F., and Smith, E.A., 2013, Electron donor concentrations in sediments and sediment properties at the agricultural chemicals team research site near New Providence, lowa, 2006-07: U.S. Geological Survey Data Series 737, $17 \mathrm{p}$ 


\section{Foreword}

The U.S. Geological Survey (USGS) is committed to providing the Nation with reliable scientific information that helps to enhance and protect the overall quality of life and that facilitates effective management of water, biological, energy, and mineral resources (http://www.usgs. gov/). Information on the Nation's water resources is critical to ensuring long-term availability of water that is safe for drinking and recreation and is suitable for industry, irrigation, and fish and wildlife. Population growth and increasing demands for water make the availability of that water, measured in terms of quantity and quality, even more essential to the long-term sustainability of our communities and ecosystems.

The USGS implemented the National Water-Quality Assessment (NAWOA) Program in 1991 to support national, regional, State, and local information needs and decisions related to water-quality management and policy (http://water.usgs.gov/nawqa). The NAWQA Program is designed to answer: What is the quality of our Nation's streams and groundwater? How are conditions changing over time? How do natural features and human activities affect the quality of streams and groundwater, and where are those effects most pronounced? By combining information on water chemistry, physical characteristics, stream habitat, and aquatic life, the NAWQA Program aims to provide science-based insights for current and emerging water issues and priorities. From 1991 to 2001, the NAWQA Program completed interdisciplinary assessments and established a baseline understanding of water-quality conditions in 51 of the Nation's river basins and aquifers, referred to as Study Units (http://water.usgs.gov/nawqa/studies/ study_units.html).

National and regional assessments are ongoing in the second decade (2001-2012) of the NAWQA Program as 42 of the 51 Study Units are selectively reassessed. These assessments extend the findings in the Study Units by determining water-quality status and trends at sites that have been consistently monitored for more than a decade, and filling critical gaps in characterizing the quality of surface water and groundwater. For example, increased emphasis has been placed on assessing the quality of source water and finished water associated with many of the Nation's largest community water systems. During the second decade, NAWQA is addressing five national priority topics that build an understanding of how natural features and human activities affect water quality, and establish links between sources of contaminants, the transport of those contaminants through the hydrologic system, and the potential effects of contaminants on humans and aquatic ecosystems. Included are studies on the fate of agricultural chemicals, effects of urbanization on stream ecosystems, bioaccumulation of mercury in stream ecosystems, effects of nutrient enrichment on aquatic ecosystems, and transport of contaminants to public-supply wells. In addition, national syntheses of information on pesticides, volatile organic compounds (VOCs), nutrients, trace elements, and aquatic ecology are continuing.

The USGS aims to disseminate credible, timely, and relevant science information to address practical and effective water-resource management and strategies that protect and restore water quality. We hope this NAWOA publication will provide you with insights and information to meet your needs, and will foster increased citizen awareness and involvement in the protection and restoration of our Nation's waters. 
The USGS recognizes that a national assessment by a single program cannot address all waterresource issues of interest. External coordination at all levels is critical for cost-effective management, regulation, and conservation of our Nation's water resources. The NAWQA Program, therefore, depends on advice and information from other agencies-Federal, State, regional, interstate, Tribal, and local—as well as nongovernmental organizations, industry, academia, and other stakeholder groups. Your assistance and suggestions are greatly appreciated.

William H. Werkheiser USGS Associate Director for Water 


\section{Acknowledgments}

Funding for this research was provided by a U.S. Geological Survey (USGS) National Institutes of Water Resources National Competitive Grant, number 2006ND126G. Assistance for this work was provided by Paul Capel and Steve Kalkhoff, both of the USGS.

The authors also gratefully acknowledge collaborations with Kanishka Marasinghe, of the University of North Dakota, and his assistance with his x-ray diffractometer.

\section{Contents}

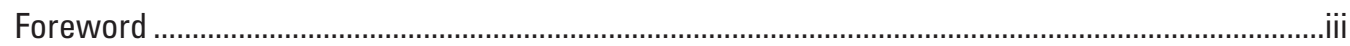

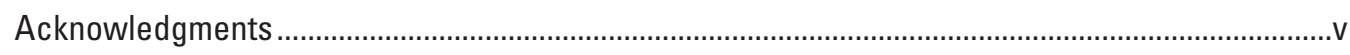

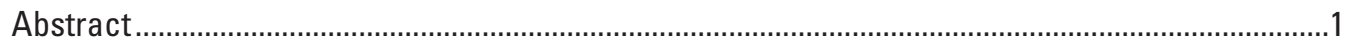

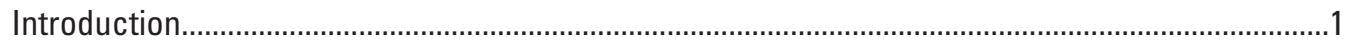

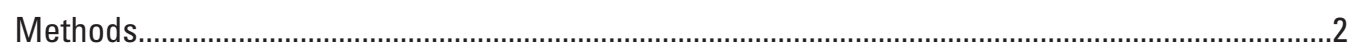

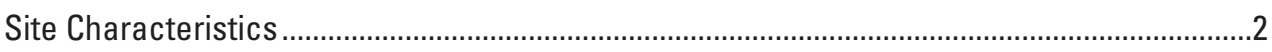

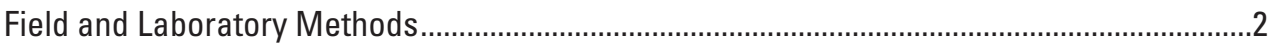

Electron Donor Concentrations and Sediment Properties ...............................................................

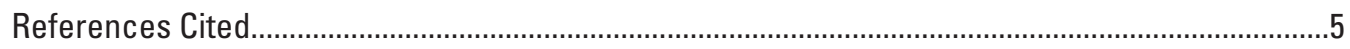

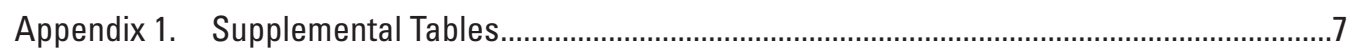

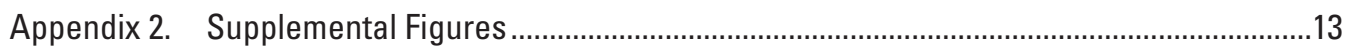

\section{Figures}

1. Map showing location of the study site and borehole sampling locations

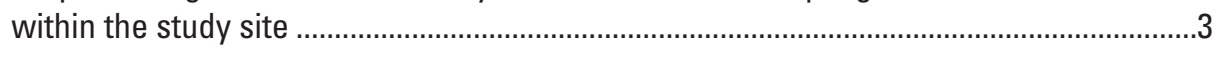

2. Graph showing $x$-ray diffraction scan of sediment sample C1 (2.44-3.66 meters)

\section{Tables}

1. Location of core sampling sites and sampling dates ...................................................

2. Quantifiable detection limits of analytical methods used for quantification of electron donors 


\section{Conversion Factors}

SI to Inch/Pound

\begin{tabular}{|c|c|c|}
\hline Multiply & By & To obtain \\
\hline \multicolumn{3}{|c|}{ Length } \\
\hline millimeter (mm) & 0.03937 & inch (in.) \\
\hline meter (m) & 3.281 & foot $(\mathrm{ft})$ \\
\hline meter $(\mathrm{m})$ & 1.094 & yard (yd) \\
\hline \multicolumn{3}{|c|}{ Mass } \\
\hline $\operatorname{gram}(\mathrm{g})$ & 0.03527 & ounce, avoirdupois (oz) \\
\hline
\end{tabular}

Temperature in degrees Celsius $\left({ }^{\circ} \mathrm{C}\right)$ may be converted to degrees Fahrenheit $\left({ }^{\circ} \mathrm{F}\right)$ as follows:

${ }^{\circ} \mathrm{F}=\left(1.8 x^{\circ} \mathrm{C}\right)+32$

Vertical coordinate information is referenced to the North American Vertical Datum of 1988 (NAVD 88).

Horizontal coordinate information is referenced to the North American Datum of 1983 (NAD 83).

Elevation, as used in this report, refers to distance above the vertical datum.

\section{Symbols}

$\begin{array}{ll}> & \text { greater than } \\ < & \text { less than } \\ \leq & \text { less than or equal to } \\ \pm & \text { plus or minus } \\ \circledR & \text { registered trademark }\end{array}$

\section{Abbreviations}

$\begin{array}{ll}\mathrm{Fe}(\mathrm{II}) & \text { ferrous iron } \\ \mathrm{HCI} & \text { hydrochloric acid } \\ \text { IC } & \text { inorganic carbon } \\ \text { IS } & \text { inorganic sulfide } \\ \text { OC } & \text { organic carbon } \\ \text { OS } & \text { organic sulfur } \\ \text { USGS } & \text { U.S. Geological Survey } \\ \text { XRD } & \text { x-ray diffraction }\end{array}$




\title{
Electron Donor Concentrations in Sediments and Sediment Properties at the Agricultural Chemicals Team Research Site near New Providence, lowa, 2006-07
}

\author{
By Bijesh Maharjan, Scott F. Korom, and Erik A. Smith
}

\begin{abstract}
The concentrations of electron donors in aquifer sediments are important to the understanding of the fate and transport of redox-sensitive constituents in groundwater, such as nitrate. For a study by the U.S. Geological Survey National Water-Quality Assessment Program, 50 sediment samples were collected from below the water table from 11 boreholes at the U.S. Geological Survey Agricultural Chemicals Team research site near New Providence, Iowa, during 2006-07. All samples were analyzed for gravel, sand (coarse, medium, and fine), silt, clay, Munsell soil color, inorganic carbon content, and for the following electron donors: organic carbon, ferrous iron, and inorganic sulfide. A subset of 14 sediment samples also was analyzed for organic sulfur, but all of these samples had concentrations less than the method detection limit; therefore, the presence of this potential electron donor was not considered further. X-ray diffraction analyses provided important semi-quantitative information of well-crystallized dominant minerals within the sediments that might be contributing electron donors.
\end{abstract}

\section{Introduction}

Nitrate is the most common groundwater contaminant, and because of growing anthropogenic sources, nitrate pollution is increasing (Korom, 1992). Nitrogen sources to groundwater can include chemical fertilizer, animal manure, wastewater, and atmospheric deposition. One of the processes by which nitrate is removed from groundwater is denitrification, which is the microbially mediated reduction of nitrate. Relatively non-reactive molecular nitrogen is the terminal product of this oxidation-reduction (redox) reaction (Korom, 1992).

There are three requirements for denitrification: bacteria capable of mediating the reaction, low oxygen concentrations, and a supply of electron donors (Firestone, 1982). Korom (1992) concluded that the supply of electron donors is the critical factor for groundwater denitrification. In the absence of these electron donors, bacteria will not reduce nitrate.
Typically, the supply of electron donors associated with subsurface sediments is larger than the supply dissolved in groundwater (Kennedy and others, 1998; Hartog and others, 2005; Everett and others, 2006). Hartog and others (2002) and Helvoort and others (2007) noted that finer fractions of sediment are more reactive than coarser fractions. Electron donors associated with denitrification include organic carbon (Korom, 1992; McMahon and others, 1999; Rivett and others, 2008), minerals bearing ferrous iron [Fe(II)] (Postma, 1990; Ernstsen, 1996; Senn and Hemond, 2002) and sulfur, both as organic (Bohlke and others, 2002) and inorganic (mainly pyrite) (Korom and others, 2005; Schwientek and others, 2008; Majumder and others, 2008) species.

The concentrations of electron donors in aquifer sediments are important to the understanding of the fate and transport of redox-sensitive constituents in groundwater, such as nitrate. A study of electron donor concentrations in sediments and sediment properties was conducted for the U.S. Geological Survey (USGS) National Water-Quality Assessment Program. For this study, 50 sediment samples were collected from below the water table from 11 boreholes at the USGS Agricultural Chemicals Team research site near New Providence, Iowa, during 2006-07. All samples were analyzed for gravel, sand (coarse, medium, and fine), silt, clay, Munsell soil color, inorganic carbon content, and for the following electron donors: organic carbon (OC), ferrous iron [Fe(II)], and inorganic sulfide (IS). A subset of 14 sediment samples also was analyzed for organic sulfur (OS), but all of these samples had concentrations less than the method detection limit; therefore, the presence of this potential electron donor was not considered further. This report summarizes the electron donor concentrations in sediments and sediment properties that were analyzed in samples collected at the research site during 2006-07. 


\section{Methods}

\section{Site Characteristics}

The South Fork Iowa River watershed is part of the Iowa River watershed and is representative of corn and soybean row cropping in the Midwest (Kalkhoff and others, 2000). The South Fork Iowa River watershed consists of a lowrelief modern flood plain underlain by alluvial deposits and till, bounded by slightly higher relief ridges. Underlying the modern flood plain, surficial deposits of the DeForest Formation are dominated by very dark gray to brown, noncalcareous to calcareous, sandy loam alluvium with variable thicknesses from less than $(<) 1$ to 5 meters (m; Quade and Giglierano, 2006). Underlying the DeForest Formation, the Noah Creek Formation consists of dark yellowish brown medium to coarse gravelly sand ranging from 4.5 to $12 \mathrm{~m}$. With some variability, the Noah Creek Formation is underlain by till deposits of the Dows Formation-Morgan Member. These till deposits are stratified loam to silt loam, grayish brown and quite variable in thickness, ranging from 3 to $5 \mathrm{~m}$ (Quade and Giglierano, 2006).

Elevations at the research site (fig. 1) range from approximately $300 \mathrm{~m}$, measured from the North American Vertical Datum of 1988, in the upper part of the watershed to approximately $285 \mathrm{~m}$. Surficial deposits near the USGS streamgage, South Fork Iowa River NE of New Providence, Iowa (USGS 05451210), are dominated by alluvium of the DeForest Formation and valley train outwash deposits of the Noah Creek Formation.

\section{Field and Laboratory Methods}

Fifty subsurface sediment samples were collected at depths below the water table from 11 boreholes at the research site (fig. 1 and table 1). A direct push coring unit (Geoprobe ${ }^{\circledR}$ Model 540MT, Salina, Kansas) mounted to a skid loader was used to collect 50 subsurface sediment samples in acrylic sleeves: 14 were collected in November 2006, 30 in May 2007, and 6 in November 2007. Upon collection, samples were capped at both ends, put on ice, and transported to the University of North Dakota for analysis. All samples were moved to plastic storage containers, homogenized by gentle mixing, labeled, and stored in high-density polyethylene containers in a freezer for subsequent analysis.

Particle sizes $<0.0625$ millimeters $(\mathrm{mm})$ were determined by the hydrometer method of sedimentation analysis, and sizes great than $(>) 0.0625 \mathrm{~mm}$ were determined by wetsieve analysis (American Society for Testing and Materials, 1998). Sediment grains were classified into gravel $(>2.0 \mathrm{~mm})$, sand [less than or equal to $(\leq) 2.0 \mathrm{~mm}$ and $>0.0625 \mathrm{~mm}$ ], silt $(\leq 0.0625 \mathrm{~mm}$ and $>0.004 \mathrm{~mm})$, and clay $(\leq 0.004 \mathrm{~mm})$. Munsell soil color classification was done for all the sediment samples.
Sediment mineralogy was analyzed by using $\mathrm{x}$-ray diffraction (XRD) with an X'Pert Advanced XRD (PANanalytical B.V.) diffractometer. To prepare the sediment samples for $\mathrm{XRD}$, about 10 grams of each sediment sample was ground with a mortar and pestle with the gravel fraction removed before grinding. The ground sediment sample was then left to air-dry overnight. The air-dried sample was then sieved through a No. 230 sieve and collected in a glass vial and labeled. Samples were kept in a sample holder and mounted in the diffractometer in sets consisting of as many as 10 samples. The XRD scans acquired from the analyses were later matched with the standard mineral database contained within the X'Pert Advanced XRD software. Two samples were scanned before and after acidification to confirm the loss of dolomite, $\mathrm{CaMg}\left(\mathrm{CO}_{3}\right)_{2}$, and calcite, $\mathrm{CaCO}_{3}$, by acidification.

Only the sediments smaller than gravel $(<2.0 \mathrm{~mm})$ were analyzed for electron donor and inorganic carbon (IC) concentrations. Each sample was first oven-dried overnight at 103 degrees Celsius and ground into fine powder before any chemical analysis. Large concentrations of IC in the subsurface sediments, if present, can obscure the quantification of OC concentrations (Shimadzu Corporation, 2001). Thus, after IC analysis and before OC analysis, IC was removed from each sample by immersing the pulverized sediment samples in water acidified to a $\mathrm{pH}<2$ with concentrated hydrochloric acid (HCl), a volatile acid (Shimadzu Corporation, 2001). Then, the acidified sediments were filtered and weighed; the mass lost during acidification was considered to be inorganic carbon. Subsequent analysis by the Shimadzu TOC analyzer, a high-temperature combustion method for determining OC concentrations (Churcher and Dickhout, 1986), confirmed that this method effectively removed inorganic carbon from the sediment samples.

Inorganic sulfide (IS) was determined by chromium reduction, modified slightly by using larger amounts of reagents (Canfield and others, 1986). Concentrations of Fe(II) were analyzed through wet chemical extraction by adopting methods used by Kennedy and others (1999). The results of total $\mathrm{Fe}(\mathrm{II})$ were computed by combining the $\mathrm{Fe}(\mathrm{II})$ recovered by the wet chemical extraction method plus $\mathrm{Fe}(\mathrm{II})$ corresponding stoichiometrically to IS [as pyrite $\left.\left(\mathrm{FeS}_{2}\right)\right]$. Concentrations of OS were analyzed using a Leco SC-432 DR Sulfur Analyzer. The detection limits of the various analytical methods for the electron donors are presented in table 2 ; the detection limit for IC was 0.003 percent.

Analyses of a standard for each electron donor were performed to assess the accuracy and precision of the analytical methods. Dextrose $\left(\mathrm{C}_{6} \mathrm{H}_{12} \mathrm{O}_{6}\right)$ was used as the standard for OC analysis and had average recoveries of 99.8 percent plus or minus ( \pm ) 3.4 percent ( 3 samples). Pyrite $\left(\mathrm{FeS}_{2}\right.$ ) was the standard for IS analysis and had average recoveries of 90.6 percent \pm 0.3 percent $\left(3\right.$ samples). For $\mathrm{Fe}(\mathrm{II})$ analysis, siderite $\left(\mathrm{FeCO}_{3}\right)$ served as the standard and had average recoveries of 88.4 percent \pm 2.3 percent ( 7 samples). 

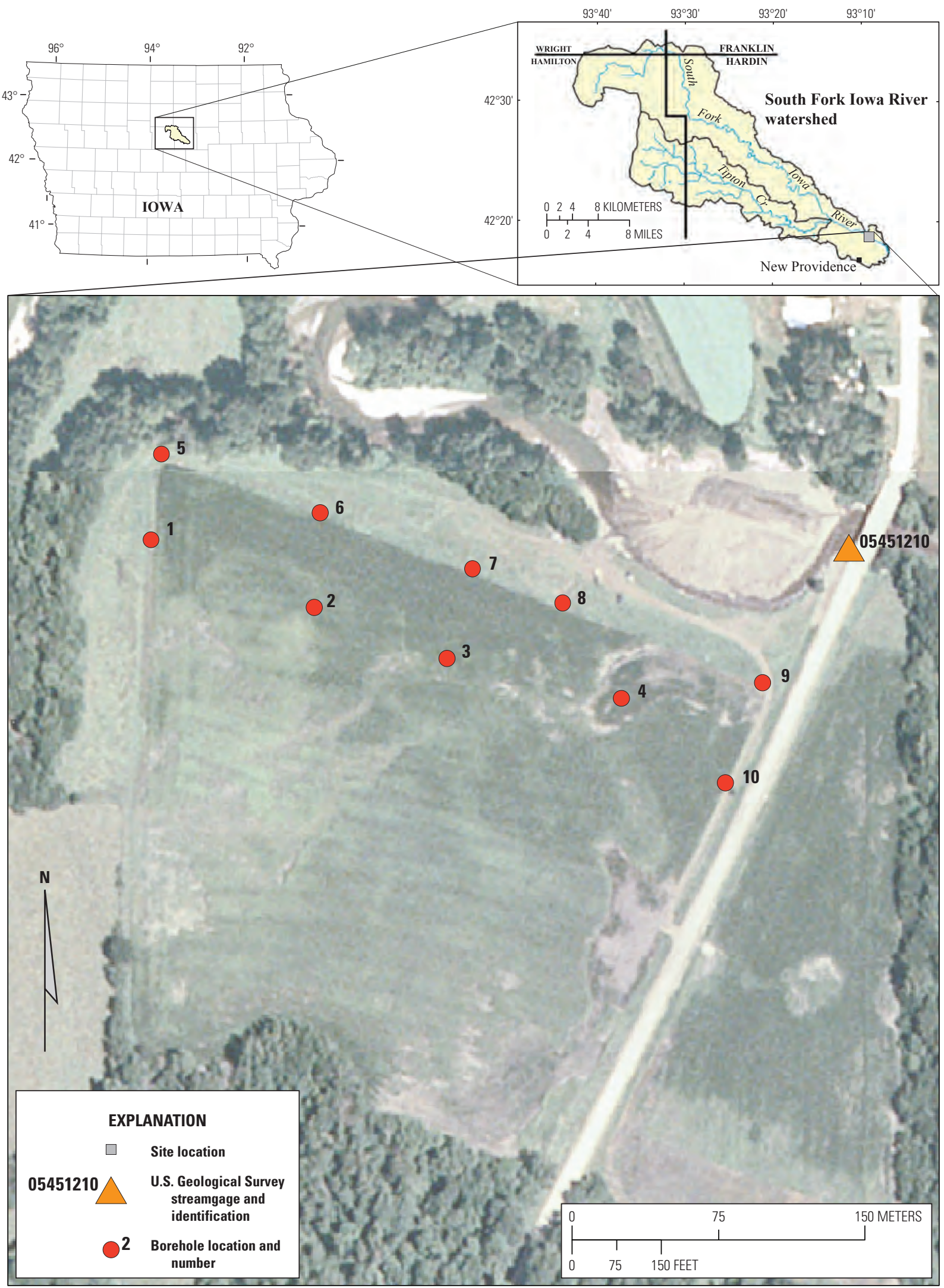

Figure 1. Location of the study site and borehole sampling locations within the study site. 
Table 1. Location of core sampling sites and sampling dates.

[Latitude and longitude, in degrees, minutes, seconds]

\begin{tabular}{|c|c|c|c|}
\hline $\begin{array}{c}\text { Core } \\
\text { no. }\end{array}$ & Latitude & Longitude & $\begin{array}{l}\text { Sampling } \\
\text { date }\end{array}$ \\
\hline 1 & $42^{\circ} 18^{\prime} 53.6 "$ & $93^{\circ} 09^{\prime} 24.6 "$ & $11-02-2006$ \\
\hline 2 & $42^{\circ} 18^{\prime} 52.5^{\prime \prime}$ & $93^{\circ} 09^{\prime} 20.2^{\prime \prime}$ & $11-02-2006$ \\
\hline 3 & $42^{\circ} 18^{\prime} 51.8^{\prime \prime}$ & $93^{\circ} 09^{\prime} 17.7$ " & $11-03-2006$ \\
\hline 4 & $42^{\circ} 18^{\prime} 51.0^{\prime \prime}$ & $93^{\circ} 09^{\prime} 14.9^{\prime \prime}$ & $11-03-2006$ \\
\hline 5 & $42^{\circ} 18^{\prime} 55.4^{\prime \prime}$ & $93^{\circ} 09^{\prime} 24.3^{\prime \prime}$ & 05-14-2006 \\
\hline 6 & $42^{\circ} 18^{\prime} 54.3^{\prime \prime}$ & $93^{\circ} 09^{\prime} 20.4^{\prime \prime}$ & 05-14-2006 \\
\hline 6.1 & $42^{\circ} 18^{\prime} 54.4^{\prime \prime}$ & $93^{\circ} 09^{\prime} 20.0^{\prime \prime}$ & $11-13-2007$ \\
\hline 7 & $42^{\circ} 18^{\prime} 53.5^{\prime \prime}$ & $93^{\circ} 09^{\prime} 17.2^{\prime \prime}$ & $05-15-2006$ \\
\hline 8 & $42^{\circ} 18^{\prime} 52.9^{\prime \prime}$ & $93^{\circ} 09^{\prime} 15.2^{\prime \prime}$ & $05-15-2006$ \\
\hline 9 & $42^{\circ} 18^{\prime} 51.7 \prime$ & $93^{\circ} 09^{\prime} 10.8^{\prime \prime}$ & 05-15-2006 \\
\hline 10 & $42^{\circ} 18^{\prime} 49.7 \prime$ & $93^{\circ} 09^{\prime} 11.8^{\prime \prime}$ & $05-15-2006$ \\
\hline
\end{tabular}

Table 2. Quantifiable detection limits of analytical methods used for quantification of electron donors.

\begin{tabular}{cc}
\hline Electron donor & $\begin{array}{c}\text { Quantifiable detection limit } \\
\text { (percent) }\end{array}$ \\
\hline Organic carbon (OC) & 0.02 \\
Inorganic sulfide (IS) & .003 \\
Ferrous iron [Fe(II)] & .003 \\
Organic sulfur (OS) & .01 \\
\hline
\end{tabular}

\section{Electron Donor Concentrations and Sediment Properties}

All 50 sediment samples were analyzed for gravel, sand (coarse, medium, and fine), silt, and clay contents. The results of the texture analysis are given in table 1-1 in appendix 1. Detailed results from the textural analyses containing the relative amounts of course, medium, and fine sand-sized fractions are presented in table 1-2 in appendix 1. The Munsell soil colors for the sediment samples are presented in table $1-3$ in appendix 1 .
The XRD scans showed a substantial amount of quartz, dolomite, and calcite in some sediment samples, with examples shown in figure $2-1$ in appendix 2 . No significant peaks for minerals potentially responsible for electron donors in the samples were found, with the exception of small peaks for amphibole and clinochlore. Both of these minerals, potentially containing $\mathrm{Fe}(\mathrm{II})$, were detected in almost all of the XRD scans. However, other related peaks of amphibole and clinoclore could not be found as verification. Commonly, $\mathrm{XRD}$ detection limits for minerals range from 1 to 3 percent, by mass, depending on background noise, peak resolution of the diffractogram pattern, and sample preparation (Zachara and others, 2004). The chemical analysis showed that all the electron donors were present at concentrations $<1$ percent by mass, which indicated that the minerals bearing Fe(II) or IS are not detectable by XRD scans. For aquifer sediment samples with poly-mineral mixtures, default searching by the X'Pert Advanced XRD software provides definitive results of the major minerals like quartz, feldspar, dolomite, and calcite. However, for Fe(II)- and IS-bearing minerals, closer observations were required. Sediment samples presented were randomly selected for XRD analysis (appendix 2) and all of them showed similar peaks, which is to be expected because all the samples analyzed were collected from the same field site.

Under $\mathrm{HCl}$ treatment as described in the "Field and Laboratory Methods" section, the sediment samples yielded IC concentrations with an average content of 9 percent by mass, with a few as high as 18 percent content (table 1-4 in appendix 1). This is to be expected because XRD scans of these sediments revealed high peaks of dolomite and calcite, as shown in figure 2. Additional XRD scans of other sediment samples from this site are included in figure $2-1$ in appendix 2.

The OC content in the sediments averaged 0.13 percent by mass. The OC concentrations are presented in table 1-4. The IS content in the sediments averaged 0.033 percent by mass, with a few samples having IS concentrations less than the detection limit of 0.003 percent (table 1-5 in appendix 1). A subset of 14 sediment samples was analyzed for OS concentrations (table 1-1), but all of these concentrations were less than the detection limit of 0.01 percent by mass. The Fe(II) content in the sediments averaged 0.24 percent by mass (table 1-6 in appendix 1). 


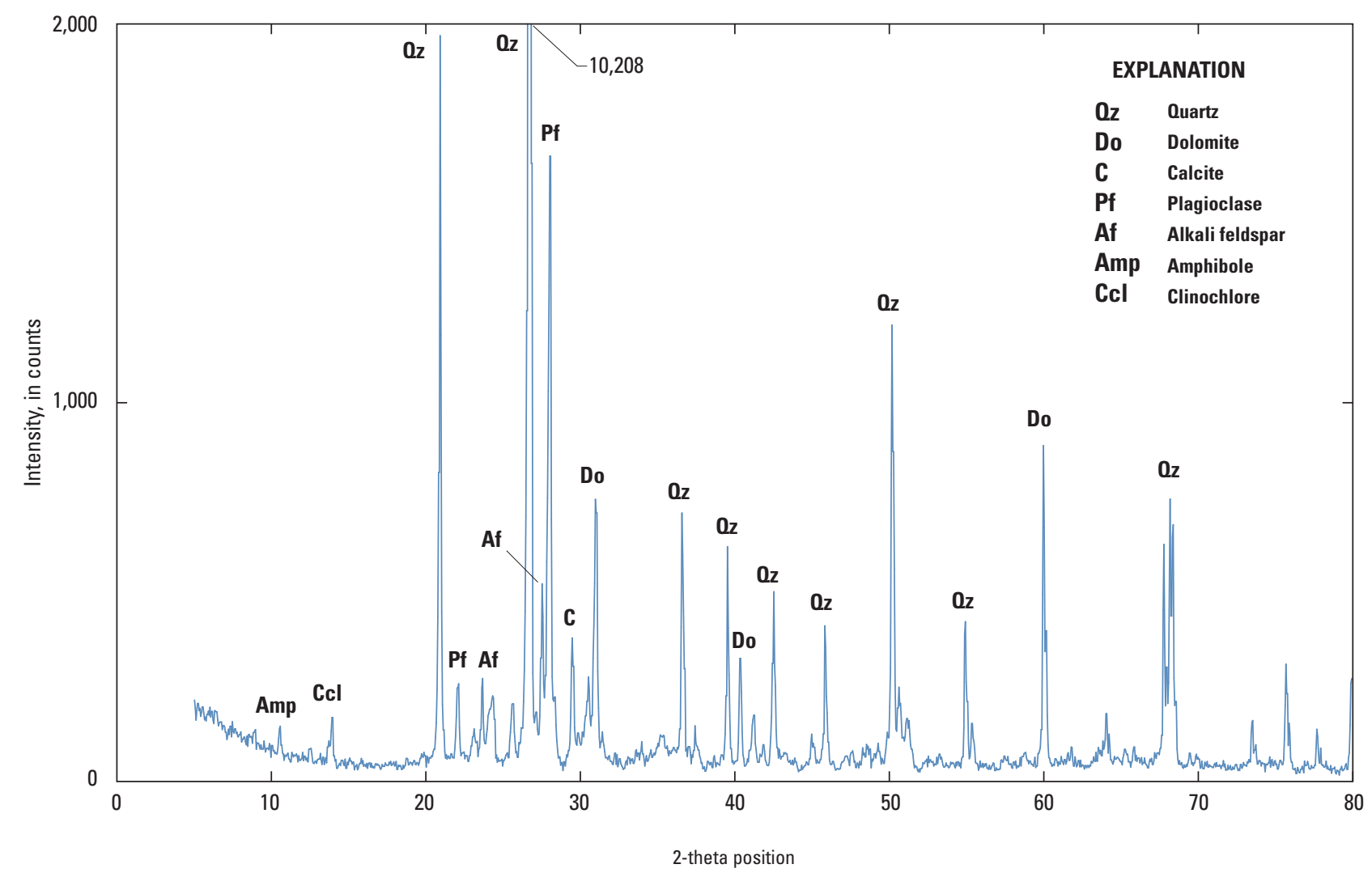

Figure 2. X-ray diffraction scan of sediment sample C1 (2.44-3.66 meters).

\section{References Cited}

American Society for Testing and Materials, 1998, Standard test method for particle-size analysis of soils, volume 04.08: West Conshohocken, Pa., American Society for Testing and Materials.

Bohlke, J.K., Wanty, R., Tuttle, M., Delin, G., and Landon, M., 2002, Denitrification in the recharge area and discharge area of a transient agricultural nitrate plume in a glacial outwash sand aquifer, Minnesota: Water Resources Research, v. 38, no. 7 , p. 10-1 to $10-26$.

Canfield, D.E., Raiswell, Robert, Westrich, J.T., Reaves, C.M., and Berner, R.A., 1986, The use of chromium reduction in the analysis of reduced inorganic sulfur in sediments and shales: Chemical Geology, v. 54, p. 149-155.

Churcher, P.L., and Dickhout, R.D., 1987, Analysis of ancient sediments for total organic carbon-Some new ideas: Journal of Geochemical Exploration, v. 29, no. 1-3, p. 235-246.

Ernstsen, Vibeke, 1996, Reduction of nitrate by $\mathrm{Fe} 2+$ in clay mineral: Clays and Clay Minerals, v. 44, no. 5, p. 599-608.
Everett, J.W., Kennedy, L.G., and Gonzales, J., 2006, Natural attenuation assessment using mineral data: Practice Periodical of Hazardous, Toxic, and Radioactive Waste Management, v. 10 , no. 4 , p. 256-263.

Firestone, M.K., 1982, Biological denitrification in agricultural soils, in Stevenson, F.J., ed., Nitrogen in agricultural soils: American Society of Agronomy Monograph 22, p. 289-326.

Hartog, Niels, Griffioen, Jasper, and Van Der Weijden, C.H., 2002, Distribution and reactivity of $\mathrm{O}_{2}$-reducing components in sediments from a layered aquifer: Environmental Science and Technology, v. 36, no. 11, p. 2,338-2,344.

Hartog, Niels, Griffioen, J., and Bergen, P.F.V., 2005, Depositional and paleohydrogeological controls on the distribution of organic matter and other reactive reductants in aquifer sediments: Chemical Geology, v. 216, p. 113-131.

Helvoort, P.V., Griffioen, J., and Hartog, N., 2007, Characterization of the reactivity of riverine heterogeneous sediments using a facies-based approach; the Rhine-Meuse delta (The Netherlands): Applied Geochemistry, v. 22, p. 2,735-2,757. 
Kalkhoff, S.J., Barnes, K.K., Becher, K.D., Savoca, M.E., Schnoebelen, D.J., Sadorf, E.M., Porter, S.D., and Sullivan, D.J., 2000, Water quality in the eastern Iowa basins, Iowa and Minnesota, 1996-98: U.S. Geological Survey Circular $1210,37 \mathrm{p}$.

Kennedy, L.G., Everett, J.W., Ware, K.J., Parsons, R., and Green, V., 1998, Iron and sulfur mineral analysis methods for natural attenuation assessments: Bioremediation Journal, v. 2 , no. 3-4, p. 259-276.

Kennedy, L.G., Everett, J.W., Dewers, T., Pickins, W., and Edwards, D., 1999, Application of mineral iron and sulfide analysis to evaluate natural attenuation at fuel contaminated site: Journal of Environmental Engineering, v. 125, no. 1, p. $47-56$.

Korom, S.F., 1992, Natural denitrification in the saturated zone-A review: Water Resources Research, v. 28, no. 6, p. 1,657-1,668.

Korom, S.F., Schlag, A.J., Schuh, W.M., and Schlag, A.K., 2005, In situ mesocosms-Denitrification in the Elk Valley aquifer: Ground Water Monitoring and Remediation, v. 25, no. 1, p. $79-89$.

Majumder, R.K., Hasnat, M.A., Hossain, S., Ikeue, K., and Machida, M., 2008, An exploration of nitrate concentrations in groundwater aquifers of central-west region of Bangladesh: Journal of Hazardous Materials, v. 159, no. 2-3, p. 536-543.
McMahon, P.B., Böhlke, J.K., and Bruce, B.W., 1999, Denitrification in marine shales in northeastern Colorado: Water Resources Research. v. 35, no. 5, p. 1,629-1,642.

Postma, Dieke, 1990, Kinetics of nitrate reduction by detrital Fe(II)-silicates: Geochimica et Cosmochimica, v. 54, no. 3, p. 903-908.

Quade, D.J., and Giglierano, J.D., 2006, Surficial geologic map of the Des Moines Lobe of Iowa; Phase 8, Hardin County: Iowa Geological Survey Open File Map OFM-06-6.

Rivett, M.O., Buss, S.R., Morgan, P., Smith, J.W.N., and Bemment, C.D., 2008, Nitrate attenuation in groundwater-A review of biogeochemical controlling processes: Water Research, v. 42, no. 16, p. 4,215-4,232.

Schwientek, Marc, Einsiedl, Florian, Stichler, Willibald, and others, 2008, Evidence for denitrification regulated by pyrite oxidation in a heterogeneous porous groundwater system: Chemical Geology, v. 255, no. 1-2, p. 60-67.

Senn, D.B., and Hemond, H.F., 2002, Nitrate controls on iron and arsenic in an urban lake: Science, v. 296, no. 5577 , p. 2,373-2,376.

Zachara, J.M., Ainsworth, C.C., Brown, G.E., Catalano, J.G., Jr., McKinley, J.P., Qafoku, O., Smith, S.C., Szecsody, J.E., Traina, S.J., and Warner, J.A., 2004, Chromium speciation and mobility in a high level nuclear waste vadose zone plume: Geochimica et Cosmochimica Acta, v. 68, no. 1, p. $13-30$. 


\section{Appendix 1. Supplemental Tables}


Table 1-1. Sample name, depth, and results of textural and chemical analyses (in percent) for the sediment samples.

[Analyses values are in percent; $\mathrm{IC}_{-} \mathrm{CO}_{3}^{-}$, inorganic carbon as carbonates; OC, organic carbon; IS, inorganic sulfide; Fe(II), ferrous iron; OS, organic sulfide; <, less than; --, not determined]

\begin{tabular}{|c|c|c|c|c|c|c|c|c|c|c|}
\hline \multicolumn{2}{|c|}{ Samples } & \multicolumn{4}{|c|}{ Texture analysis } & \multicolumn{5}{|c|}{ Chemical analysis } \\
\hline $\begin{array}{c}\text { Borehole } \\
\text { no. }\end{array}$ & $\begin{array}{c}\text { Depth } \\
\text { (meters) }\end{array}$ & Gravel & Total sand & Silt & Clay & IC-CO & OC & IS & $\mathrm{Fe}(\mathrm{II})$ & OS \\
\hline B 1 & $2.44-3.66$ & 5.18 & 86.49 & 4.82 & 3.51 & 7.41 & 0.063 & 0.026 & 0.237 & -- \\
\hline B 1 & $3.66-4.88$ & 41.83 & 50.08 & 6.27 & 1.82 & 13.25 & .035 & .037 & .662 & -- \\
\hline B 1 & $5.79-6.10$ & 4.17 & 30.78 & 53.15 & 11.9 & 17.06 & .359 & .147 & .783 & -- \\
\hline B 2 & $3.35-3.51$ & 35.35 & 55.01 & 7.89 & 1.75 & 8.58 & .186 & .022 & .286 & -- \\
\hline B 2 & $3.51-3.66$ & 47.94 & 27.16 & 20.22 & 4.68 & 6.98 & .558 & .181 & .577 & -- \\
\hline B 2 & $3.66-3.96$ & 8.6 & 35.75 & 41.31 & 14.34 & 15.56 & .294 & .179 & .934 & -- \\
\hline B 2 & $5.79-6.10$ & 4.75 & 89.63 & 3.89 & 1.72 & 3.79 & .035 & .029 & .153 & -- \\
\hline B 2 & $7.01-7.32$ & 1.44 & 92.27 & 4.59 & 1.7 & 2.25 & .024 & .029 & .17 & -- \\
\hline B 3 & $2.44-2.59$ & 20.77 & 73.89 & 4.48 & .86 & 5.49 & .044 & .019 & .17 & -- \\
\hline B 3 & $3.66-3.81$ & 47.26 & 46.24 & 6.5 & .5 & 10.36 & .02 & .011 & .144 & -- \\
\hline B 3 & $6.10-6.71$ & 40.4 & 54.31 & 4.44 & .84 & 9 & .018 & .014 & .211 & -- \\
\hline B 4 & $2.44-2.74$ & 26.96 & 68.86 & 4.17 & .5 & 2.65 & .051 & .0015 & .113 & -- \\
\hline B 4 & $4.57-4.88$ & .62 & 92.41 & 2.56 & 4.41 & 8.47 & .04 & .0015 & .221 & -- \\
\hline B 4 & $7.01-7.32$ & 1.31 & 92.8 & 3.26 & 2.63 & 10.2 & .058 & .118 & .445 & -- \\
\hline B 5 & $2.13-2.44$ & .78 & 16.41 & 70.94 & 11.88 & 8.93 & 2.064 & .0015 & .586 & -- \\
\hline B 5 & $2.44-3.66$ & 50.2 & 39.78 & 10.02 & .5 & 5.89 & .057 & .0015 & .131 & -- \\
\hline B 5 & $3.66-4.88$ & 60.61 & 36.33 & 3.05 & .5 & 12.36 & .05 & .0015 & .061 & -- \\
\hline B 5 & $5.49-6.10$ & 17.46 & 82.54 & 0 & .5 & 9.96 & .01 & .0015 & .128 & -- \\
\hline B 5 & $6.10-6.86$ & 27.91 & 70.03 & 0 & 2.05 & 10.16 & .055 & .061 & .335 & -- \\
\hline B 6 & $2.13-2.44$ & 4.65 & 77.52 & 15.69 & 2.13 & 1.74 & .215 & .01 & .149 & -- \\
\hline B 6 & $2.44-3.66$ & 27.21 & 60.81 & 11.98 & .5 & 7.15 & .079 & .007 & .167 & -- \\
\hline B 6 & $3.66-4.88$ & 41.89 & 50.27 & 7.84 & .5 & 10.03 & .01 & .002 & .149 & -- \\
\hline B 6 & $4.88-5.18$ & 13.91 & 81.03 & 5.06 & .5 & 9.34 & .01 & .006 & .132 & -- \\
\hline B 6 & $6.71-7.32$ & 20 & 72.39 & 4.89 & 2.73 & 10.14 & .02 & .006 & .144 & -- \\
\hline В 6.1 & $2.44-3.05$ & 33.6 & 52.41 & 10.53 & 3.45 & 6.43 & .127 & .016 & .16 & $<0.01$ \\
\hline В 6.1 & $3.05-3.66$ & 43.8 & 42.77 & 7.88 & 5.57 & 14.11 & .117 & .012 & .129 & $<.01$ \\
\hline В 6.1 & $3.66-4.27$ & 21.32 & 70.35 & 4.51 & 3.81 & 12.19 & .01 & .015 & .131 & $<.01$ \\
\hline В 6.1 & $4.27-4.88$ & 16.92 & 78.63 & 1.92 & 2.52 & 10.22 & .01 & .019 & .141 & $<.01$ \\
\hline В 6.1 & $4.88-5.33$ & 42.04 & 49.9 & 4.79 & 3.27 & 10.9 & .01 & .012 & .132 & $<.01$ \\
\hline В 6.1 & $5.33-5.79$ & 29.28 & 63.12 & 4.6 & 2.99 & 9.19 & .01 & .016 & .113 & $<.01$ \\
\hline B 7 & $2.13-2.44$ & 1.21 & 95.52 & 3.28 & .5 & 1.99 & .026 & .003 & .082 & -- \\
\hline B 7 & $2.44-3.66$ & 1.6 & 92.12 & 6.29 & .5 & 2.18 & .223 & .008 & .199 & -- \\
\hline B 7 & $4.88-5.18$ & 13.11 & 80.46 & 6.43 & .5 & 8.3 & .021 & .114 & .256 & -- \\
\hline B 7 & $7.01-7.32$ & 38.44 & 56 & 3.76 & 1.79 & 9.11 & .01 & .002 & .139 & -- \\
\hline B 8 & $2.13-2.44$ & .46 & 73.5 & 19.2 & 6.85 & 3.88 & .204 & .008 & .135 & -- \\
\hline B 8 & $3.05-3.66$ & 47.12 & 44.75 & 7.1 & 1.03 & 7.51 & .045 & .003 & .108 & -- \\
\hline B 8 & $3.66-4.27$ & 44.14 & 47.87 & 3.83 & 4.14 & 10.11 & .068 & .057 & .262 & -- \\
\hline B 8 & $5.79-6.10$ & 18.11 & 75.46 & 2.14 & 4.29 & 9.83 & .048 & .06 & .298 & -- \\
\hline B 8 & $6.10-6.40$ & 15.21 & 80.85 & 0.74 & 3.19 & 3.22 & .032 & .022 & .155 & -- \\
\hline B 8 & $7.01-7.32$ & 37.41 & 54.8 & 4.17 & 3.62 & 10.08 & .05 & .054 & .304 & -- \\
\hline B 9 & $2.13-2.44$ & 0.37 & 87.07 & 11.62 & .93 & 2.1 & .121 & .004 & .093 & -- \\
\hline B 9 & $3.35-3.66$ & 39.84 & 49.14 & 10.16 & .87 & 7.67 & .167 & .083 & .319 & -- \\
\hline B 9 & $4.57-4.88$ & 0 & 84.99 & 13.17 & 1.84 & 9.38 & .142 & .126 & .65 & $<.01$ \\
\hline B 9 & $5.79-6.10$ & 32.67 & 62.76 & 4.56 & .5 & 8.26 & .041 & .043 & .383 & $<.01$ \\
\hline B 9 & $6.10-6.40$ & 45.56 & 46.78 & 5.96 & 1.71 & 7.02 & .04 & .021 & .132 & $<.01$ \\
\hline B 10 & $2.13-2.44$ & 2.97 & 79.06 & 11.47 & 6.49 & 3.2 & .032 & .003 & .05 & $<.01$ \\
\hline B 10 & $3.05-3.66$ & 38.91 & 47.78 & 8.99 & 4.31 & 15.15 & .01 & .004 & .156 & $<.01$ \\
\hline B 10 & $4.57-4.88$ & 29 & 50.69 & 14.23 & 6.09 & 18.06 & .71 & .004 & .181 & $<.01$ \\
\hline B 10 & $5.79-6.10$ & 17.1 & 78.1 & 1.18 & 3.64 & 8.48 & .023 & .012 & .127 & $<.01$ \\
\hline B 10 & $7.01-7.32$ & 30.25 & 59.97 & 5.3 & 4.48 & 18.2 & .132 & .013 & .178 & $<.01$ \\
\hline
\end{tabular}


Table 1-2. Texture analysis of the sediment samples with the sand fraction sub-divided into coarse, medium, and fine sand.

[Analyses values are in percent; <, less than]

\begin{tabular}{|c|c|c|c|c|c|c|c|c|}
\hline \multicolumn{2}{|c|}{ Samples } & \multirow{3}{*}{ Gravel } & \multicolumn{4}{|c|}{ Texture analysis } & \multirow{3}{*}{ Silt } & \multirow{3}{*}{ Clay } \\
\hline \multirow{2}{*}{$\begin{array}{c}\text { Borehole } \\
\text { no. }\end{array}$} & \multirow{2}{*}{$\begin{array}{l}\text { Depth } \\
\text { (meters) }\end{array}$} & & \multicolumn{4}{|c|}{ Sand } & & \\
\hline & & & Coarse & Medium & Fine & Total & & \\
\hline B 1 & $2.44-3.66$ & 5.18 & 42.63 & 30.53 & 13.33 & 86.49 & 4.82 & 3.51 \\
\hline B 1 & $3.66-4.88$ & 41.83 & 35.83 & 7.75 & 6.5 & 50.08 & 6.27 & 1.82 \\
\hline B 1 & $5.79-6.10$ & 4.17 & 7.4 & 6.29 & 17.09 & 30.78 & 53.15 & 11.9 \\
\hline B 2 & $3.35-3.51$ & 35.35 & 38.16 & 7.81 & 9.04 & 55.01 & 7.89 & 1.75 \\
\hline B 2 & $3.51-3.66$ & 47.94 & 12.08 & 4.59 & 10.49 & 27.16 & 20.22 & 4.68 \\
\hline B 2 & $3.66-3.96$ & 8.6 & 11.11 & 9.77 & 14.87 & 35.75 & 41.31 & 14.34 \\
\hline B 2 & $5.79-6.10$ & 4.75 & 26.34 & 39.72 & 23.57 & 89.63 & 3.89 & 1.72 \\
\hline B 2 & $7.01-7.32$ & 1.44 & 6.72 & 35.29 & 50.26 & 92.27 & 4.59 & 1.7 \\
\hline B 3 & $2.44-2.59$ & 20.77 & 33.81 & 32.7 & 7.38 & 73.89 & 4.48 & .86 \\
\hline B 3 & $3.66-3.81$ & 47.26 & 29.13 & 13.38 & 3.73 & 46.24 & 6.5 & $<1$ \\
\hline B 3 & $6.10-6.71$ & 40.4 & 27.41 & 19.82 & 7.08 & 54.31 & 4.44 & .84 \\
\hline B 4 & $2.44-2.74$ & 26.96 & 10.88 & 25.6 & 32.38 & 68.86 & 4.17 & .5 \\
\hline B 4 & $4.57-4.88$ & .62 & 22.75 & 49.38 & 20.28 & 92.41 & 2.56 & 4.41 \\
\hline B 4 & $7.01-7.32$ & 1.31 & 21.56 & 51 & 20.24 & 92.8 & 3.26 & 2.63 \\
\hline B 5 & $2.13-2.44$ & .78 & 3.91 & 3.59 & 8.91 & 16.41 & 70.94 & 11.88 \\
\hline B 5 & $2.44-3.66$ & 50.2 & 19.7 & 12.8 & 7.28 & 39.78 & 10.02 & .5 \\
\hline B 5 & $3.66-4.88$ & 60.61 & 24.85 & 6.25 & 5.23 & 36.33 & 3.05 & .5 \\
\hline B 5 & $5.49-6.10$ & 17.46 & 50 & 24.44 & 8.1 & 82.54 & 0 & .5 \\
\hline B 5 & $6.10-6.86$ & 27.91 & 51.47 & 15.62 & 2.94 & 70.03 & 0 & 2.05 \\
\hline B 6 & $2.13-2.44$ & 4.65 & 7.71 & 30.05 & 39.76 & 77.52 & 15.69 & 2.13 \\
\hline B 6 & $2.44-3.66$ & 27.21 & 22.79 & 23.57 & 14.45 & 60.81 & 11.98 & .5 \\
\hline B 6 & $3.66-4.88$ & 41.89 & 27.79 & 16.76 & 5.72 & 50.27 & 7.84 & .5 \\
\hline B 6 & $4.88-5.18$ & 13.91 & 31.72 & 41.61 & 7.7 & 81.03 & 5.06 & .5 \\
\hline B 6 & $6.71-7.32$ & 20 & 25.23 & 23.75 & 23.41 & 72.39 & 4.89 & 2.73 \\
\hline В 6.1 & $2.44-3.05$ & 33.6 & 23.96 & 16.81 & 11.64 & 52.41 & 10.53 & 3.45 \\
\hline В 6.1 & $3.05-3.66$ & 43.8 & 29.13 & 8.35 & 5.29 & 42.77 & 7.88 & 5.57 \\
\hline В 6.1 & $3.66-4.27$ & 21.32 & 42.36 & 23.13 & 4.86 & 70.35 & 4.51 & 3.81 \\
\hline В 6.1 & $4.27-4.88$ & 16.92 & 38.47 & 35.28 & 4.88 & 78.63 & 1.92 & 2.52 \\
\hline В 6.1 & $4.88-5.33$ & 42.04 & 26.58 & 14.4 & 8.92 & 49.9 & 4.79 & 3.27 \\
\hline В 6.1 & $5.33-5.79$ & 29.28 & 22.26 & 17.25 & 23.61 & 63.12 & 4.6 & 2.99 \\
\hline B 7 & $2.13-2.44$ & 1.21 & 22.01 & 51.94 & 21.57 & 95.52 & 3.28 & .5 \\
\hline B 7 & $2.44-3.66$ & 1.6 & 19.61 & 47.2 & 25.31 & 92.12 & 6.29 & .5 \\
\hline B 7 & $4.88-5.18$ & 13.11 & 22.75 & 47.51 & 10.2 & 80.46 & 6.43 & .5 \\
\hline B 7 & $7.01-7.32$ & 38.44 & 27.69 & 20.25 & 8.06 & 56 & 3.76 & 1.79 \\
\hline B 8 & $2.13-2.44$ & .46 & 21.57 & 25.22 & 26.71 & 73.5 & 19.2 & 6.85 \\
\hline B 8 & $3.05-3.66$ & 47.12 & 20.02 & 16.83 & 7.9 & 44.75 & 7.1 & 1.03 \\
\hline B 8 & $3.66-4.27$ & 44.14 & 30.57 & 11.81 & 5.49 & 47.87 & 3.83 & 4.14 \\
\hline B 8 & $5.79-6.10$ & 18.11 & 46.2 & 22.29 & 6.97 & 75.46 & 2.14 & 4.29 \\
\hline B 8 & $6.10-6.40$ & 15.21 & 30.53 & 38.72 & 11.6 & 80.85 & .74 & 3.19 \\
\hline B 8 & $7.01-7.32$ & 37.41 & 37.77 & 12.14 & 4.89 & 54.8 & 4.17 & 3.62 \\
\hline B 9 & $2.13-2.44$ & .37 & 4.2 & 28.68 & 54.19 & 87.07 & 11.62 & .93 \\
\hline B 9 & $3.35-3.66$ & 39.84 & 22.92 & 13.11 & 13.11 & 49.14 & 10.16 & .87 \\
\hline B 9 & $4.57-4.88$ & 0 & 0.09 & 4.97 & 79.93 & 84.99 & 13.17 & 1.84 \\
\hline B 9 & $5.79-6.10$ & 32.67 & 32.76 & 17.18 & 12.82 & 62.76 & 4.56 & .5 \\
\hline B 9 & $6.10-6.40$ & 45.56 & 16.87 & 15.27 & 14.64 & 46.78 & 5.96 & 1.71 \\
\hline В 10 & $2.13-2.44$ & 2.97 & 4.36 & 22.55 & 52.15 & 79.06 & 11.47 & 6.49 \\
\hline В 10 & $3.05-3.66$ & 38.91 & 27.17 & 12.59 & 8.02 & 47.78 & 8.99 & 4.31 \\
\hline B 10 & $4.57-4.88$ & 29 & 32.31 & 10.8 & 7.58 & 50.69 & 14.23 & 6.09 \\
\hline B 10 & $5.79-6.10$ & 17.1 & 29.73 & 36.64 & 11.73 & 78.1 & 1.18 & 3.64 \\
\hline B 10 & $7.01-7.32$ & 30.25 & 41.35 & 13.16 & 5.46 & 59.97 & 5.3 & 4.48 \\
\hline
\end{tabular}


Table 1-3. Munsell soil color for the sediment samples at the study site.

\begin{tabular}{|c|c|c|c|}
\hline \multicolumn{2}{|c|}{ Samples } & \multicolumn{2}{|c|}{$\begin{array}{l}\text { Munsell soil color } \\
\text { (moist sample) }\end{array}$} \\
\hline $\begin{array}{c}\text { Borehole } \\
\text { no. }\end{array}$ & $\begin{array}{c}\text { Depth } \\
\text { (meters) }\end{array}$ & Notation & Color \\
\hline B 1 & $2.44-3.66$ & $2.5 \mathrm{Y} 3 / 2$ & very dark grayish brown \\
\hline B 1 & $3.66-4.88$ & $5 \mathrm{Y} 4 / 2$ & olive gray \\
\hline B 1 & $5.79-6.10$ & $1 \mathrm{GLEY} 2.5 / \mathrm{N}$ & black \\
\hline B 2 & $3.35-3.51$ & 5YR 5/6 & yellowish red \\
\hline B 2 & $3.51-3.66$ & $1 \mathrm{GLEY} 2.5 / \mathrm{N}$ & black \\
\hline B 2 & $3.66-3.96$ & 1 GLEY 3/10Y & dark greenish gray \\
\hline B 2 & $5.79-6.10$ & 1 GLEY 5/10Y & greenish gray \\
\hline B 2 & $7.01-7.32$ & 1 GLEY 3/10Y & dark greenish gray \\
\hline B 3 & $2.44-2.59$ & $7.5 \mathrm{YR} 5 / 2$ & brown \\
\hline B 3 & $3.66-3.81$ & 7.5 YR 6/6 & reddish yellow \\
\hline B 3 & $6.10-6.71$ & 7.5 YR 6/4 & light brown \\
\hline B 4 & $2.44-2.74$ & 7.5 YR $3 / 2$ & dark brown \\
\hline B 4 & $4.57-4.88$ & $5 \mathrm{YR} 5 / 3$ & reddish brown \\
\hline B 4 & $7.01-7.32$ & 1 GLEY 3/10GY & dark greenish gray \\
\hline B 5 & $2.13-2.44$ & $2.5 Y 2.5 / 1$ & black \\
\hline B 5 & $2.44-3.66$ & $10 \mathrm{R} 3 / 4$ & dusky red \\
\hline B 5 & $3.66-4.88$ & 10YR 5/6 & yellowish brown \\
\hline B 5 & $5.49-6.10$ & $5 Y R 4 / 4$ & reddish brown \\
\hline B 5 & $6.10-6.86$ & 1 GLEY 4/1 & dark greenish gray \\
\hline B 6 & $2.13-2.44$ & 5 YR $2.5 / 2$ & dark reddish brown \\
\hline B 6 & $2.44-3.66$ & 2.5 Y 5/4 & light olive brown \\
\hline B 6 & $3.66-4.88$ & $2.5 \mathrm{Y} 6 / 3$ & light yellowish brown \\
\hline B 6 & $4.88-5.18$ & $2.5 \mathrm{Y} 6 / 4$ & light yellowish brown \\
\hline B 6 & $6.71-7.32$ & $2.5 \mathrm{Y} 6 / 3$ & light yellowish brown \\
\hline B 6.1 & $2.44-3.05$ & 1 GLEY 2.5/10Y & greenish black \\
\hline B 6.1 & $3.05-3.66$ & $10 \mathrm{YR} 5 / 2$ & grayish brown \\
\hline B 6.1 & $3.66-4.27$ & $10 \mathrm{R} 6 / 3$ & pale red \\
\hline B 6.1 & $4.27-4.88$ & $10 \mathrm{R} 6 / 6$ & light red \\
\hline B 6.1 & $4.88-5.33$ & $2.5 \mathrm{YR} 3 / 2$ & dark reddish brown \\
\hline B 6.1 & $5.33-5.79$ & $10 \mathrm{R} 6 / 6$ & light red \\
\hline B 7 & $2.13-2.44$ & 5YR 5/4 & reddish brown \\
\hline B 7 & $2.44-3.66$ & $2.5 \mathrm{Y} 3 / 2$ & very dark grayish brown \\
\hline B 7 & $4.88-5.18$ & 7.5 YR $6 / 3$ & light brown \\
\hline B 7 & $7.01-7.32$ & 2.5 Y $5 / 4$ & light olive brown \\
\hline B 8 & $2.13-2.44$ & $10 \mathrm{R} 2.5 / 1$ & reddish black \\
\hline B 8 & $3.05-3.66$ & $5 \mathrm{YR} 4 / 3$ & reddish brown \\
\hline B 8 & $3.66-4.27$ & 1 GLEY 6/1 & greenish gray \\
\hline B 8 & $5.79-6.10$ & 1 GLEY 6/5GY & greenish gray \\
\hline B 8 & $6.10-6.40$ & $5 \mathrm{YR} 5 / 4$ & reddish brown \\
\hline B 8 & $7.01-7.32$ & 1 GLEY 4/5GY & dark grayish gray \\
\hline B 9 & $2.13-2.44$ & $2.5 \mathrm{YR} 3 / 2$ & dusky red \\
\hline B 9 & $3.35-3.66$ & $10 \mathrm{YR} 4 / 2$ & dark grayish brown \\
\hline B 9 & $4.57-4.88$ & 1 GLEY 4/10GY & dark grayish gray \\
\hline B 9 & $5.79-6.10$ & 1 GLEY 5/5GY & greenish gray \\
\hline B 9 & $6.10-6.40$ & $2.5 \mathrm{YR} 6 / 3$ & light reddish brown \\
\hline B 10 & $2.13-2.44$ & $2.5 \mathrm{YR} 3 / 3$ & dark reddish brown \\
\hline B 10 & $3.05-3.66$ & $10 \mathrm{YR} 7 / 6$ & yellow \\
\hline B 10 & $4.57-4.88$ & $5 \mathrm{Y} 7 / 3$ & pale yellow \\
\hline B 10 & $5.79-6.10$ & $5 \mathrm{YR} 5 / 4$ & reddish brown \\
\hline B 10 & $7.01-7.32$ & $2.5 \mathrm{Y} 6 / 3$ & light yellowish brown \\
\hline
\end{tabular}


Table 1-4. Organic and inorganic carbon concentrations of the individual sediment samples.

$\left[\mathrm{IC}-\mathrm{CO}_{3}{ }^{2-}\right.$, inorganic carbon as carbonates; $<$, less than]

\begin{tabular}{|c|c|c|c|c|}
\hline \multicolumn{2}{|c|}{ Samples } & \multirow{3}{*}{$\begin{array}{l}\text { IC- } \mathrm{CO}_{3}{ }^{2-} \\
\text { (percent) }\end{array}$} & \multirow{2}{*}{\multicolumn{2}{|c|}{$\begin{array}{l}\text { Organic carbon } \\
\text { (percent) }\end{array}$}} \\
\hline \multirow{2}{*}{$\begin{array}{l}\text { Borehole } \\
\text { no. }\end{array}$} & \multirow{2}{*}{$\begin{array}{c}\text { Depth } \\
\text { (meters) }\end{array}$} & & & \\
\hline & & & Run 1 & Run 2 \\
\hline B 1 & $2.44-3.66$ & 7.405 & 0.068 & 0.059 \\
\hline B 1 & $3.66-4.88$ & 13.251 & .037 & .032 \\
\hline B 1 & $5.79-6.10$ & 17.058 & .348 & .369 \\
\hline B 2 & $3.35-3.51$ & 8.579 & .188 & .184 \\
\hline B 2 & $3.51-3.66$ & 6.976 & .588 & .528 \\
\hline B 2 & $3.66-3.96$ & 15.556 & .299 & .29 \\
\hline B 2 & $5.79-6.10$ & 3.791 & .045 & .026 \\
\hline B 2 & $7.01-7.32$ & 2.247 & .017 & .03 \\
\hline B 3 & $2.44-2.59$ & 5.491 & .042 & .046 \\
\hline B 3 & $3.66-3.81$ & 10.361 & .018 & $<.020$ \\
\hline B 3 & $6.10-6.71$ & 9.004 & .019 & .017 \\
\hline B 4 & $2.44-2.74$ & 2.654 & .054 & .049 \\
\hline B 4 & $4.57-4.88$ & 8.467 & .05 & .031 \\
\hline B 4 & $7.01-7.32$ & 10.205 & .065 & .051 \\
\hline B 5 & $2.13-2.44$ & 8.931 & 2.091 & 2.037 \\
\hline B 5 & $2.44-3.66$ & 5.885 & .054 & .06 \\
\hline B 5 & $3.66-4.88$ & 12.363 & .048 & $<.020$ \\
\hline B 5 & $5.49-6.10$ & 9.965 & $<.020$ & $<.020$ \\
\hline B 5 & $6.10-6.86$ & 10.163 & .045 & .065 \\
\hline B 6 & $2.13-2.44$ & 1.745 & .216 & .214 \\
\hline B 6 & $2.44-3.66$ & 7.146 & .071 & .087 \\
\hline B 6 & $3.66-4.88$ & 10.034 & $<.020$ & $<.020$ \\
\hline B 6 & $4.88-5.18$ & 9.343 & $<.020$ & $<.020$ \\
\hline B 6 & $6.71-7.32$ & 10.137 & $<.020$ & .022 \\
\hline В 6.1 & $2.44-3.05$ & 6.427 & .126 & .128 \\
\hline В 6.1 & $3.05-3.66$ & 14.111 & .125 & .109 \\
\hline В 6.1 & $3.66-4.27$ & 12.194 & $<.020$ & $<.020$ \\
\hline В 6.1 & $4.27-4.88$ & 10.218 & $<.020$ & $<.020$ \\
\hline В 6.1 & $4.88-5.33$ & 10.896 & $<.020$ & $<.020$ \\
\hline В 6.1 & $5.33-5.79$ & 9.19 & $<.020$ & .012 \\
\hline B 7 & $2.13-2.44$ & 1.986 & .029 & .022 \\
\hline B 7 & $2.44-3.66$ & 2.176 & .216 & .231 \\
\hline B 7 & $4.88-5.18$ & 8.302 & .022 & .019 \\
\hline B 7 & $7.01-7.32$ & 9.109 & .012 & .012 \\
\hline B 8 & $2.13-2.44$ & 3.882 & .207 & .201 \\
\hline B 8 & $3.05-3.66$ & 7.509 & .038 & .053 \\
\hline B 8 & $3.66-4.27$ & 10.107 & .077 & .059 \\
\hline B 8 & $5.79-6.10$ & 9.827 & .046 & .05 \\
\hline B 8 & $6.10-6.40$ & 3.222 & .042 & .022 \\
\hline B 8 & $7.01-7.32$ & 10.077 & .045 & .055 \\
\hline B 9 & $2.13-2.44$ & 2.102 & .183 & .059 \\
\hline B 9 & $3.35-3.66$ & 7.666 & .179 & .156 \\
\hline B 9 & $4.57-4.88$ & 9.38 & .13 & .153 \\
\hline B 9 & $5.79-6.10$ & 8.26 & .042 & .039 \\
\hline B 9 & $6.10-6.40$ & 7.024 & .006 & .035 \\
\hline B 10 & $2.13-2.44$ & 3.202 & .048 & .016 \\
\hline B 10 & $3.05-3.66$ & 15.148 & .007 & $<.020$ \\
\hline B 10 & $4.57-4.88$ & 18.058 & .697 & .722 \\
\hline B 10 & $5.79-6.10$ & 8.483 & .024 & .022 \\
\hline B 10 & $7.01-7.32$ & 18.205 & .146 & .117 \\
\hline
\end{tabular}


Table 1-5. Inorganic sulfur concentrations for the sediment samples from the study site.

$[<$, less than; --, not determined]

\begin{tabular}{|c|c|c|c|}
\hline \multicolumn{2}{|c|}{ Samples } & \multicolumn{2}{|c|}{$\begin{array}{l}\text { Inorganic sulfur } \\
\text { (percent) }\end{array}$} \\
\hline $\begin{array}{c}\text { Borehole } \\
\text { no. }\end{array}$ & $\begin{array}{c}\text { Depth } \\
\text { (meters) }\end{array}$ & Run 1 & Run 2 \\
\hline B 1 & $2.44-3.66$ & 0.026 & 0.026 \\
\hline B 1 & $3.66-4.88$ & .06 & -- \\
\hline B 1 & $5.79-6.10$ & .089 & -- \\
\hline B 2 & $3.35-3.51$ & .033 & -- \\
\hline B 2 & $3.51-3.66$ & .224 & -- \\
\hline B 2 & $3.66-3.96$ & .102 & -- \\
\hline B 2 & $5.79-6.10$ & .027 & -- \\
\hline B 2 & $7.01-7.32$ & .028 & -- \\
\hline B 3 & $2.44-2.59$ & .024 & -- \\
\hline B 3 & $3.66-3.81$ & .016 & -- \\
\hline B 3 & $6.10-6.71$ & .012 & -- \\
\hline B 4 & $2.44-2.74$ & $<.003$ & $<.003$ \\
\hline B 4 & $4.57-4.88$ & $<.003$ & -- \\
\hline B 4 & $7.01-7.32$ & .119 & -- \\
\hline B 5 & $2.13-2.44$ & $<.003$ & -- \\
\hline B 5 & $2.44-3.66$ & $<.003$ & -- \\
\hline B 5 & $3.66-4.88$ & $<.003$ & -- \\
\hline B 5 & $5.49-6.10$ & $<.003$ & -- \\
\hline B 5 & $6.10-6.86$ & .07 & -- \\
\hline B 6 & $2.13-2.44$ & .007 & .01 \\
\hline B 6 & $2.44-3.66$ & .01 & -- \\
\hline B 6 & $3.66-4.88$ & .002 & -- \\
\hline B 6 & $4.88-5.18$ & .004 & -- \\
\hline B 6 & $6.71-7.32$ & .007 & -- \\
\hline В 6.1 & $2.44-3.05$ & .017 & -- \\
\hline В 6.1 & $3.05-3.66$ & .015 & -- \\
\hline В 6.1 & $3.66-4.27$ & .011 & -- \\
\hline В 6.1 & $4.27-4.88$ & .018 & -- \\
\hline В 6.1 & $4.88-5.33$ & .017 & -- \\
\hline В 6.1 & $5.33-5.79$ & .013 & -- \\
\hline B 7 & $2.13-2.44$ & .002 & -- \\
\hline B 7 & $2.44-3.66$ & .008 & -- \\
\hline B 7 & $4.88-5.18$ & .129 & -- \\
\hline B 7 & $7.01-7.32$ & .003 & -- \\
\hline B 8 & $2.13-2.44$ & .005 & -- \\
\hline B 8 & $3.05-3.66$ & .005 & -- \\
\hline B 8 & $3.66-4.27$ & .054 & -- \\
\hline B 8 & $5.79-6.10$ & .041 & -- \\
\hline B 8 & $6.10-6.40$ & .021 & -- \\
\hline B 8 & $7.01-7.32$ & .074 & -- \\
\hline B 9 & $2.13-2.44$ & .003 & -- \\
\hline B 9 & $3.35-3.66$ & .137 & -- \\
\hline B 9 & $4.57-4.88$ & .076 & -- \\
\hline B 9 & $5.79-6.10$ & .063 & -- \\
\hline B 9 & $6.10-6.40$ & .026 & -- \\
\hline B 10 & $2.13-2.44$ & .002 & -- \\
\hline B 10 & $3.05-3.66$ & .006 & -- \\
\hline B 10 & $4.57-4.88$ & .003 & -- \\
\hline B 10 & $5.79-6.10$ & .011 & -- \\
\hline B 10 & $7.01-7.32$ & .015 & -- \\
\hline
\end{tabular}


Table 1-6. Ferrous iron concentrations for the sediment samples from the study site.

$[\mathrm{Fe}(\mathrm{II})<$ ferrous iron; --, not determined]

\begin{tabular}{|c|c|c|c|c|c|}
\hline \multicolumn{2}{|c|}{ Samples } & \multicolumn{4}{|c|}{$\mathrm{Fe}(\mathrm{II})$ (percent) } \\
\hline \multirow{2}{*}{$\begin{array}{c}\text { Bore- } \\
\text { hole } \\
\text { no. }\end{array}$} & \multirow{2}{*}{$\begin{array}{c}\text { Depth } \\
\text { (meters) }\end{array}$} & \multicolumn{3}{|c|}{ Non-pyritic } & \multirow{2}{*}{$\begin{array}{l}\text { Pyrite } \\
\mathrm{Fe}(\text { II) }\end{array}$} \\
\hline & & Run 1 & Run 2 & Average & \\
\hline B 1 & $2.44-3.66$ & 0.214 & -- & 0.214 & 0.023 \\
\hline B 1 & $3.66-4.88$ & .63 & 0.626 & .628 & .034 \\
\hline B 1 & $5.79-6.10$ & .655 & -- & .655 & .128 \\
\hline B 2 & $3.35-3.51$ & .267 & -- & .267 & .019 \\
\hline B 2 & $3.51-3.66$ & .42 & -- & .42 & .157 \\
\hline B 2 & $3.66-3.96$ & .778 & .768 & .773 & .161 \\
\hline B 2 & $5.79-6.10$ & .128 & -- & .128 & .025 \\
\hline B 2 & $7.01-7.32$ & .145 & -- & .145 & .025 \\
\hline B 3 & $2.44-2.59$ & .154 & -- & .154 & .016 \\
\hline B 3 & $3.66-3.81$ & .135 & -- & .135 & .009 \\
\hline B 3 & $6.10-6.71$ & .199 & -- & .199 & .012 \\
\hline B 4 & $2.44-2.74$ & .112 & -- & .112 & .001 \\
\hline B 4 & $4.57-4.88$ & .22 & -- & .22 & .001 \\
\hline B 4 & $7.01-7.32$ & .341 & -- & .341 & .104 \\
\hline B 5 & $2.13-2.44$ & .584 & -- & .584 & .002 \\
\hline B 5 & $2.44-3.66$ & .131 & -- & .131 & 0 \\
\hline B 5 & $3.66-4.88$ & .061 & -- & .061 & 0 \\
\hline B 5 & $5.49-6.10$ & .127 & -- & .127 & .001 \\
\hline B 5 & $6.10-6.86$ & .283 & -- & .283 & .052 \\
\hline B 6 & $2.13-2.44$ & .141 & -- & .141 & .008 \\
\hline B 6 & $2.44-3.66$ & .161 & -- & .161 & .006 \\
\hline B 6 & $3.66-4.88$ & .148 & -- & .148 & .001 \\
\hline B 6 & $4.88-5.18$ & .126 & -- & .126 & .006 \\
\hline B 6 & $6.71-7.32$ & .138 & -- & .138 & .006 \\
\hline В 6.1 & $2.44-3.05$ & .146 & -- & .146 & .014 \\
\hline В 6.1 & $3.05-3.66$ & .118 & -- & .118 & .011 \\
\hline В 6.1 & $3.66-4.27$ & .118 & -- & .118 & .013 \\
\hline В 6.1 & $4.27-4.88$ & .125 & -- & .125 & .018 \\
\hline В 6.1 & $4.88-5.33$ & .122 & -- & .122 & .01 \\
\hline В 6.1 & $5.33-5.79$ & .099 & -- & .099 & .014 \\
\hline B 7 & $2.13-2.44$ & .079 & -- & .079 & .003 \\
\hline B 7 & $2.44-3.66$ & .192 & -- & .192 & .007 \\
\hline B 7 & $4.88-5.18$ & .157 & -- & .157 & .099 \\
\hline B 7 & $7.01-7.32$ & .137 & -- & .137 & .002 \\
\hline B 8 & $2.13-2.44$ & .128 & -- & .128 & .007 \\
\hline B 8 & $3.05-3.66$ & .106 & -- & .106 & .002 \\
\hline B 8 & $3.66-4.27$ & .212 & -- & .212 & .05 \\
\hline B 8 & $5.79-6.10$ & .246 & -- & .246 & .052 \\
\hline B 8 & $6.10-6.40$ & .136 & -- & .136 & .019 \\
\hline B 8 & $7.01-7.32$ & .257 & -- & .257 & .047 \\
\hline B 9 & $2.13-2.44$ & .09 & -- & .09 & .003 \\
\hline B 9 & $3.35-3.66$ & .247 & -- & .247 & .072 \\
\hline B 9 & $4.57-4.88$ & .54 & -- & .54 & .11 \\
\hline B 9 & $5.79-6.10$ & .346 & -- & .346 & .037 \\
\hline B 9 & $6.10-6.40$ & .114 & -- & .114 & .018 \\
\hline В 10 & $2.13-2.44$ & .048 & .045 & .046 & .004 \\
\hline В 10 & $3.05-3.66$ & .153 & -- & .153 & .003 \\
\hline B 10 & $4.57-4.88$ & .178 & -- & .178 & .003 \\
\hline B 10 & $5.79-6.10$ & .116 & -- & .116 & .011 \\
\hline B 10 & $7.01-7.32$ & .167 & -- & .167 & .011 \\
\hline
\end{tabular}




\section{Appendix 2. Supplemental Figures}




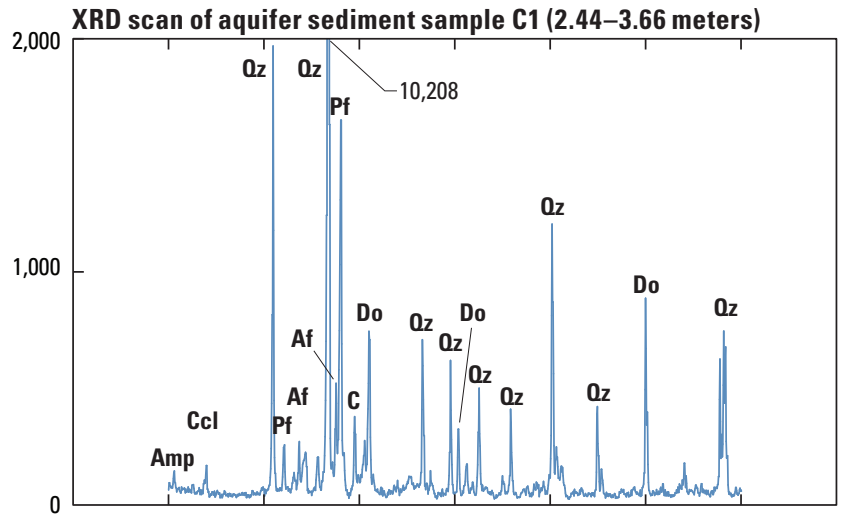

XRD scan of aquifer sediment sample C2 (3.51-3.66 meters)
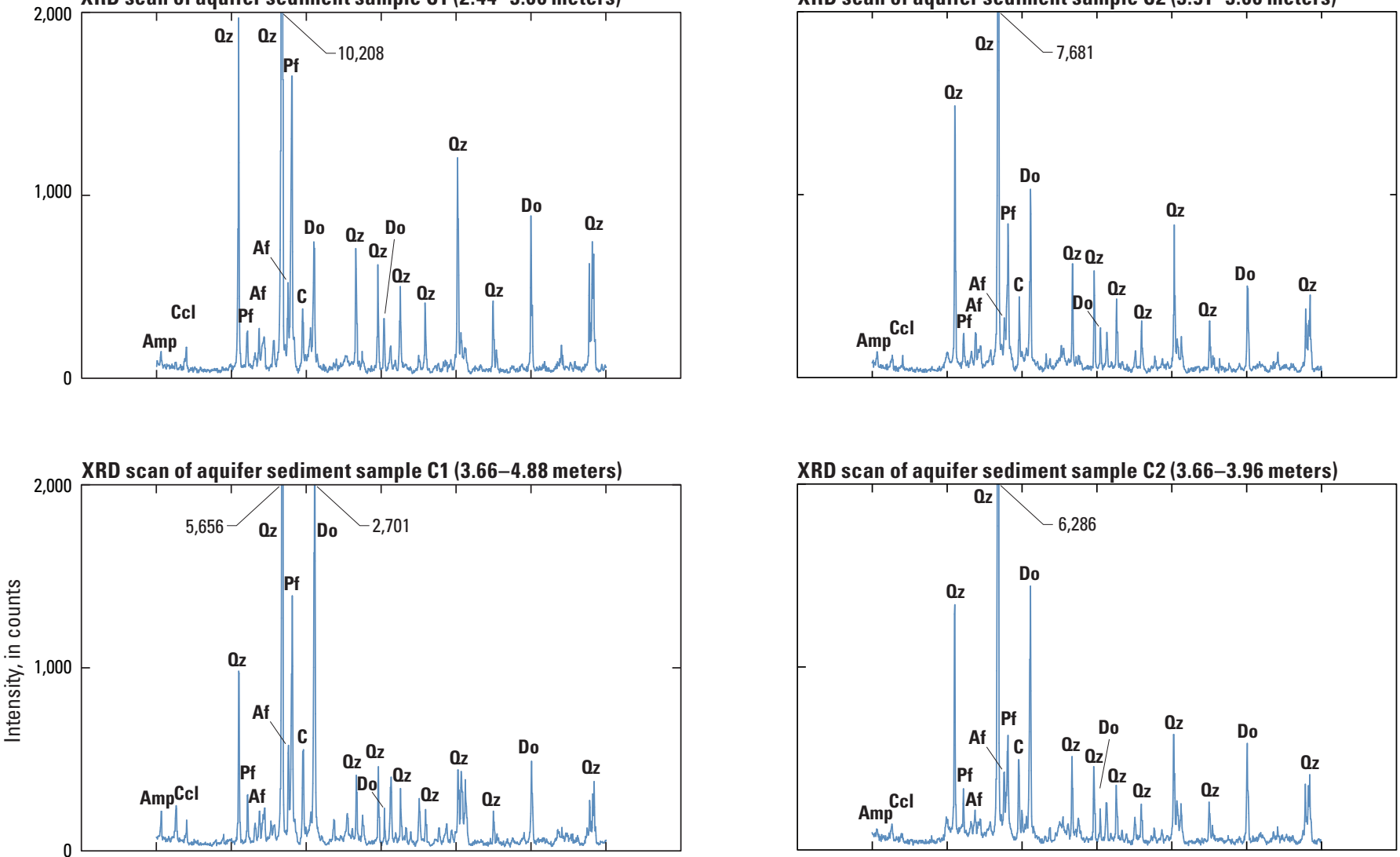

XRD scan of aquifer sediment sample C2 (3.66-3.96 meters)
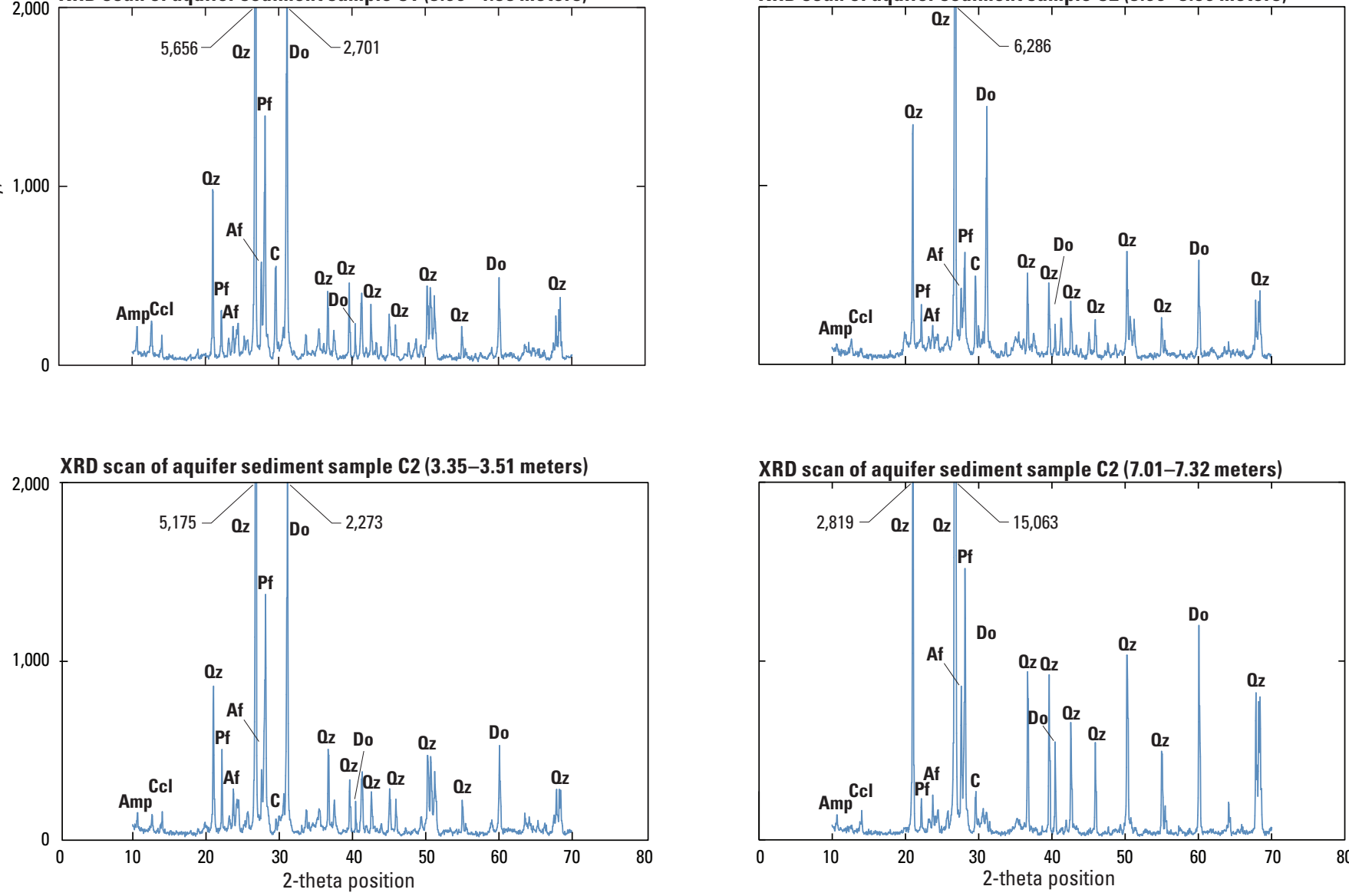

XRD scan of aquifer sediment sample C2 (7.01-7.32 meters)

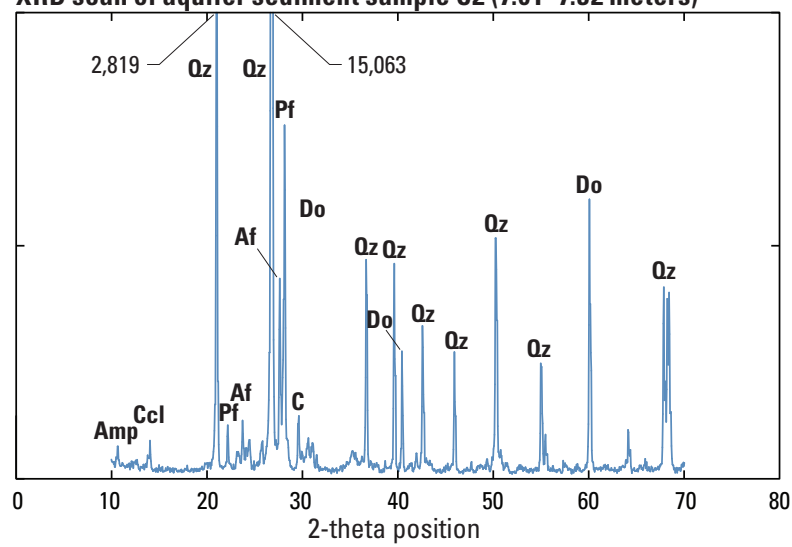

EXPLANATION

$\begin{array}{llll}\text { Oz } & \text { Quartz } & \text { Af } & \text { Alkali feldspar } \\ \text { Do } & \text { Dolomite } & \text { Amp } & \text { Amphibole } \\ \text { C } & \text { Calcite } & \text { Ccl } & \text { Clinochlore } \\ \text { Pf } & \text { Plagioclase } & & \end{array}$

Figure 2-1. Selected x-ray diffraction (XRD) scans of aquifer sediments. 
XRD scan of aquifer sediment sample C3 (2.44-2.59 meters)
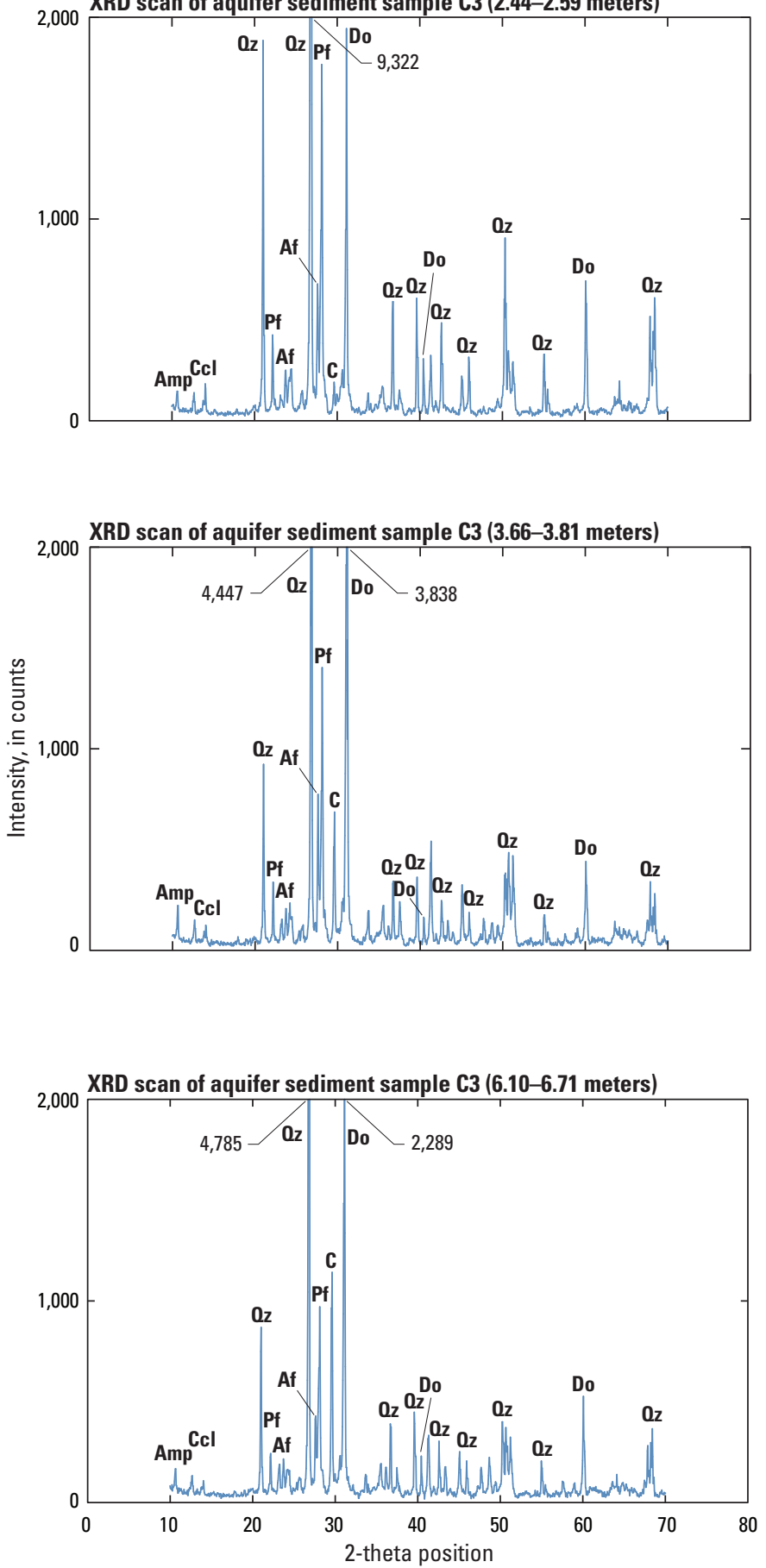

XRD scan of aquifer sediment sample C4 (2.44-2.74 meters)

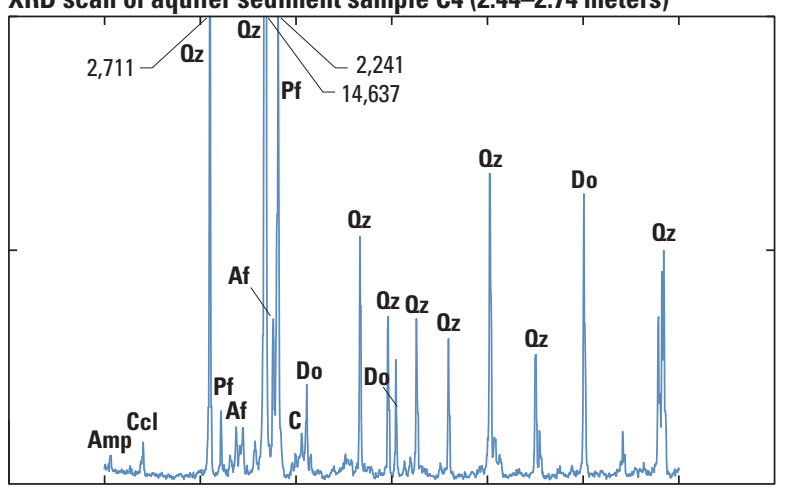

XRD scan of aquifer sediment sample C4 (4.57-4.88 meters)

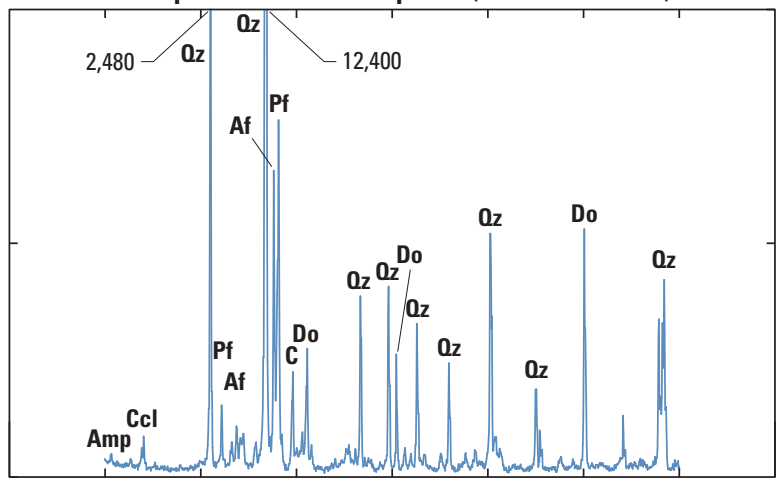

XRD scan of aquifer sediment sample C5 (6.10-6.86 meters)

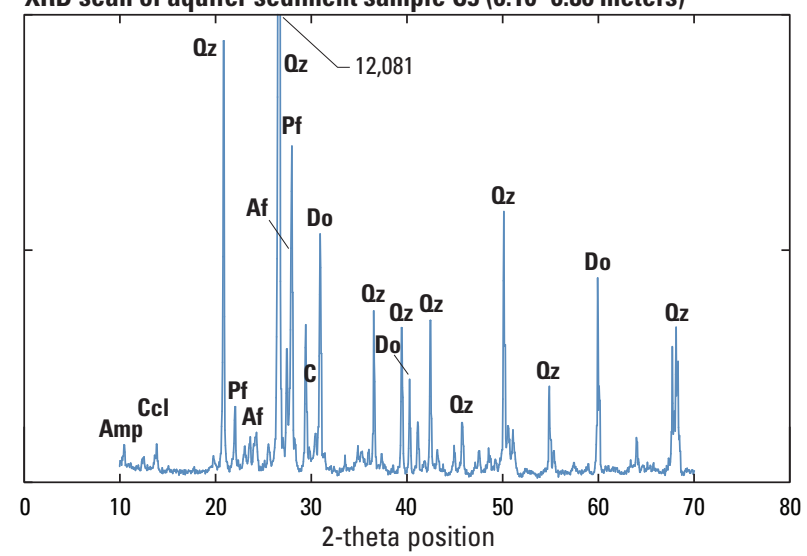

\section{EXPLANATION}

$\begin{array}{llll}\text { Oz } & \text { Quartz } & \text { Af } & \text { Alkali feldspar } \\ \text { Do } & \text { Dolomite } & \text { Amp } & \text { Amphibole } \\ \text { C } & \text { Calcite } & \text { Ccl } & \text { Clinochlore } \\ \text { Pf } & \text { Plagioclase } & & \end{array}$

Figure 2-1. Selected $x$-ray diffraction (XRD) scans of aquifer sediments.-Continued 


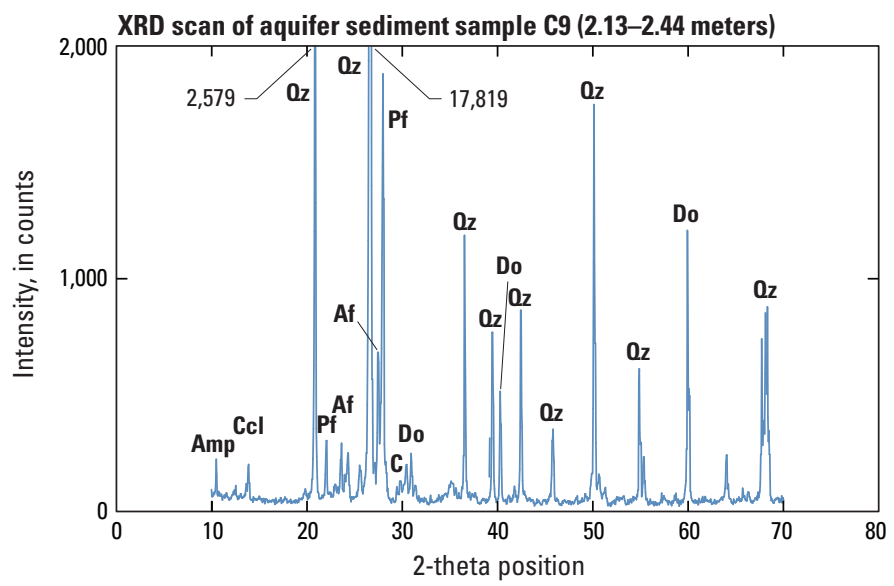

XRD scan of aquifer sediment sample C10 (2.13-2.44 meters)

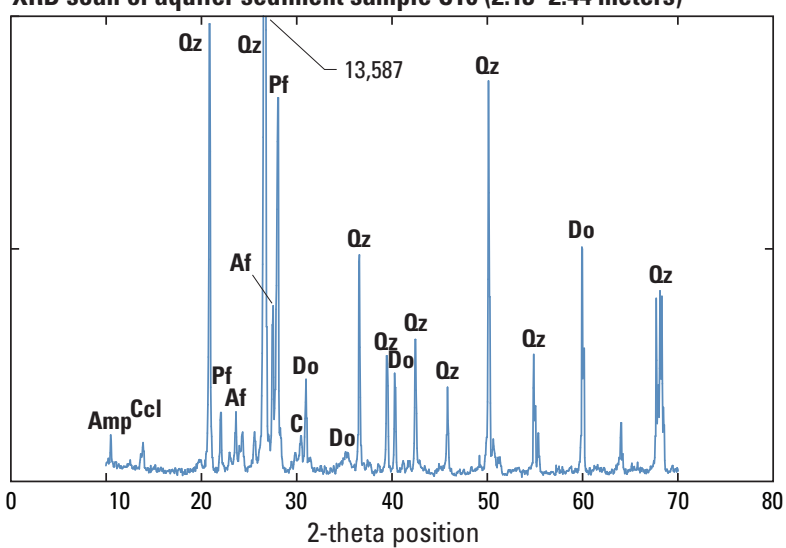

\section{EXPLANATION}

$\begin{array}{llll}\text { Oz } & \text { Quartz } & \text { Af } & \text { Alkali feldspar } \\ \text { Do } & \text { Dolomite } & \text { Amp } & \text { Amphibole } \\ \text { C } & \text { Calcite } & \text { Ccl } & \text { Clinochlore } \\ \text { Pf } & \text { Plagioclase } & & \end{array}$

Figure 2-1. Selected x-ray diffraction (XRD) scans of aquifer sediments.-Continued 
Publishing support provided by the Rolla Publishing Service Center. 



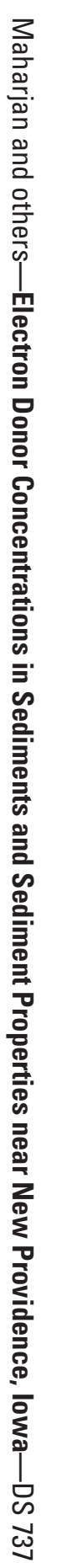

